\title{
Molecular Study of Cellulase Gene Transcription Regulatory Elements via EMS Mutagenesis in a Novelthermophilic Cellulytic Bacillus sp.
}

\author{
Ebtesam Basheer $^{1}$, Ehab Salman ${ }^{2}$ \\ ${ }^{1}$ Department of Biology, College of Science, University of Misan, Iraq \\ Ebtesambasheer[at]uomisan.edu.iq \\ ebtesambasheer[at]gmail.com \\ ${ }^{2}$ Department of Biotechnology, College of Science, University of Baghdad, Iraq \\ ehabdawood3232000[at]scbaghdad.edu.iq
}

\begin{abstract}
Cellulose is the most common biomass on the globe and is available as huge amounts of agricultural and forestry natural residues. Microbial cellulases are the major enzymes widely used in degrading cellulose. Naturally cellulytic microorganisms need to be induced to increase their cellulytic activity. In this study, EMS chemicalmutagen was used to increase cellulytic activity in the novel thermophilic Bacillus sp. isolate isolated from Iraqi soil. Sequencing results of cellulase gene transcription regulatory elements postEMS mutagenesis showed a change in the nucleotides sequence. This change was accompanied by a significant increase in cellulase quantitative activity and total cellulase activity.
\end{abstract}

Keywords: Cellulase gene, transcription regulatory element, thermophilic cellulytic Bacillus

\section{Introduction}

Cellulose constitutes the most common organic polymer. It represents about $1.5 \times 10^{12}$ tons of the annually total biomass production through photosynthesis, especially in the tropical areas. It is considered to be the most abundant and renewable biopolymer on earth and the dominating waste material from agriculture (Klemm et al., 2002).

The enzymatic depolymerization is environmental friendly (Juturu and $\mathrm{Wu}, 2014$ ). Therefore, attention was focused on the sources of microbial cellulases, i.e. bacterial and fungal cellulases (Abdullah et al., 2016). Biodegradation of cellulose by bacteria and fungi is accomplished by these extracellular cellulolytic enzymes which are encoded by genes which are subjected to transcriptional control (Ali et al., 2014).

The most common cellulolytic bacterial genera are Bacillus spp., Cellulomonasspp., Clostridium spp., Thermonosporaspp., Pseudomonas spp., Streptomyces spp. and Salmonella spp. (Menendez et al., 2015). Thermophilic Bacillusspp. is a well-studied group due to its potency in producing enzymes of industrial importance and is one of the most studied genera among the thermophilic microorganisms (Ibrahim and El-diwany, 2007 ; Kazeemet al., 2016).

Ethyl methane sulfonate was reported as a potent mutagen in Bacillus spp. (Karanam and Medicherla, 2008). It can induce mutations at a rate of $5 \times 10^{-2}$ to $5 \times 10^{-4}$ per gene without substantial killing (Haq et al., 2009).

In this study, a novel thermophilic Bacillus sp. isolate isolated from Iraqi soil was treated with EMS in different concentrations to improve its cellulytic ability. The developed mutants were screened and evaluated for enzyme production level.

\section{Methods}

\subsection{Isolation of organisms}

Thermophilic Bacillus sp. was isolated from soil samples which were collected from the soil beneath plant wastes. The isolate was identified as Bacillus sp. biochemically by reference to Acharya et al. (2012). The Vitek2 tests were also performed for more precise identification confirmation.

2.2 Screening of Bacillus isolate for thermophilic cellulase degradation ability

The experiments were set up as described by Kauri and Kushner (1985).

The $\mathrm{pH}$ of the medium was adjusted to (7.3-7.5).Five grams of each sample was inoculated into a (250) ml erylynmyer flask containing $100 \mathrm{ml}$ of sterilized CMC broth, then incubated at $(55) \mathrm{C}^{\mathrm{o}}$ for $(24) \mathrm{hrs}$. After that, (0.2) $\mathrm{ml}$ was taken from each flask and spreaded onto $\mathrm{CMC}$ agar plates then incubated at $(55) \mathrm{C}^{\circ}$ for (24) hrs.

\subsection{Qualitative screening}

The ability of the selected isolates to produce cellulase on a solid medium was examined according to Yeoh et al. (1985) and Bai et al. (2012) with modifications. The diameter of the hydrolysis halo which indicates the production of cellulase was measured.

2.4 Selection and preparation of the chosen bacterial isolate for mutagenesis

After statistically analyzing the hydrolysis halo measurements of all samples by ANOVA test using (SPSS) program; the best isolate in cellulase production, named B16, was molecularly characterized using

Volume 6 Issue 12, December 2017 


\section{International Journal of Science and Research (IJSR) \\ ISSN (Online): 2319-7064}

Index Copernicus Value (2016): 79.57 | Impact Factor (2015): 6.391

16SrRNA typing table (6).This isolate was further tested for its semi-quantitative activity which was performed according to Ponnambalam et al., (2011).Quantitative cellulytic activity and total cellulase activity or what is termed filter paper assay (FPA or FPase) assays were carried out according to Samira et al. (2011).

\subsection{Mutagenesis of thermophilic cellulytic bacterial isolate}

The chosen thermophilic isolate B16, was exposed to EMS chemical agent in an attempt to increase its total cellulytic and cellulytic quantitative activity. Mutagenesis of the selected isolate with EMS was carried out according to Haq et al. (2009) with modifications. The concentrations used were $(0,50,100,150) \mu \mathrm{g} / \mathrm{ml}$. The qualitative, semiquantitative, quantitative and FPase activity assays were performed to find out the most effective concentration in increasing cellulytic activity and then, via primers especially designed for this study by Dr. Ehab D. Salman, sequencing was performed on the transcription regulatory elements of cellulase gene for the best cellulytic mutated isolate and was compared with the sequence of regulatory elements ofB 16 control (wild) isolate.

\section{Results and Discussion}

\subsection{Isolation and identification of isolates}

Fifty one samples were isolated from soil beneath the plant wastes, characterized and identified based on their morphological and cultural properties. According to statistical analysis by ANOVA processed on the qualitative screening values, four of the isolates were chosen to be subjected to biochemical tests; the results in table (1) showed that they were Bacillus spp. Subsequently, the isolates were subjected to VITEK 2 identification for more precise identification of the isolates. The results in tables (2, 3, 4 and 5) showed that two isolates (B16 and B39) had an identification with Bacillus licheniformis by the percentage (89)\% and (93)\%, respectively. To certify the identification, the two isolates B16 and B39 were molecularly characterized depending on 16SrRNA gene and more specifically via gyrase $b$ gene. The primers for 16S rRNA gene of Bacillus sp. were designed according to Waldeck et al., (2006) table (6), while the primers specific to Bacillus licheniformis gyrase b gene were designed according to Huang et al., (2012) table (6). Both isolates had been amplified for 16S rRNA gene while had not been amplified for gyrase $b$ gene which means that both isolates are Bacillus spp. while not B.licheniformis. This agrees with Huang et al. (2012).After additional tests, the (B16) isolate was chosen to be mutated by EMS chemical agentmutagen.

\subsection{Mutagenesis}

To study the effects of EMS on the regulatory elements i.e., the promoter and the terminator of the cellulase gene, B16 isolate was subjected to different concentrations of this chemical mutagen; these treatments induce random mutations which may enhance or decrease the thermophilic cellulase production. This was deduced from estimating the enzyme activity by the three methods qualitative, semi-quantitative and quantitative activity in addition to estimating FPase activity, all of these tests, preand post-treatment as illustrated in the table (7).

After sequencing, the alignment results for the wild B16 isolate and the B16 EMS treatment had showed, for the promoter region [that contains Shine-Dalgarno (SD)which is a sequence of ribosomal binding site in bacterial and archaeal messenger RNA, generally located around 8 bases upstream of the start codon AUG; the RNA sequence helps recruit the ribosome to the messenger RNA (mRNA) to initiate protein synthesis by aligning the ribosome with the start codon, it has the general consensus sequence AGGAGG, Malys, 2012)], a deletion in the locus (-13) which lies in the (SD) sequence, figure (1).Also, the promoter contains the -10 region (Pribnow box) and -35 region. For the Pribnow box region, there were no changes in the B16 isolate sequence alignment post-EMS treatment. The same result was noticed for -35 region. For terminator region, no changes were observed in the sequence alignment post- EMS treatment, figure (2). The table (8) illustrates post-mutagenesis changes in the promoter and terminator regions briefly.

Statistical analysis results, which indicate to an increase in the different types of enzyme activity assays values in the EMS treatment at $(50) \mu \mathrm{g} / \mathrm{ml}$ with a significant difference $(P<0.05)$, refer to the positive role of EMS mutagen on thermophilic cellulase production and agrees with Mala et al., (2001) who found an over-production of the bacterial products randomly in some colonies of the mutant postEMS treatment.

The EMS is a mutagenic alkylating agent whose mode of action is attributed to the alkylation of nitrogen position 7 of guanosine of the DNA molecule (Ho and Chor, 2015), this agent carries one, two or more alkyl groups in reactive form. The transfer of ethyl or methyl groups to the bases leads to the alteration of their base-pairing resulting in transition mutation. The majority (99\%) of the mutations caused by EMS induces $\mathrm{C}$ - to $\mathrm{T}$ - changes resulting in $\mathrm{C} / \mathrm{G}$ to T/A substitutions. At a low frequency, EMS generates $\mathrm{G} / \mathrm{C}$ to $\mathrm{C} / \mathrm{G}$ or $\mathrm{G} / \mathrm{C}$ to $\mathrm{T} / \mathrm{A}$ transversions by 7-ethylguanine hydrolysis or $\mathrm{A} / \mathrm{T}$ to $\mathrm{G} / \mathrm{C}$ transition by 3-ethyladenine pairing errors. Therefore, it induces all types of mutations i.e. transition, transversion, frame shift and even chromosome aberrations with different frequencies (Kim et al., 2006; Karanam and Medicherla, 2008). The point mutations (transition, transversions and frameshifts) are minor changes in the primary structure of DNA resulting in occasional base-pairing mistakes ; while segment mutations (deletions, inversions, translocations, and duplications) leading to inactivation, chromosomal rearrangements, and chromosomal breaks, are believed to cause lethal DNA alterations because of the severe changes in the primary and secondary structure of DNA (Rhaese and Boetker, 1973).The point mutation which has the effect of an amino acid substitution may produce a mutant protein with a partial loss of activity, or occasionally an increase in activity (Minde et al., 2011). 


\section{International Journal of Science and Research (IJSR) \\ ISSN (Online): 2319-7064 \\ Index Copernicus Value (2016): 79.57 | Impact Factor (2015): 6.391}

The increase in the enzyme activity leads to the conclusion that the EMS might had induced a point mutation of an amino acid substitution which might be because of the insertion of a new amino acid in the peptide chain resulted from the mutant coding sequence of cellulase gene which had led to an improvement of cellulase activity or it might be because of a point mutation in another locus of the bacterial chromosome which had a positive effect on the cellulase gene regulation or performance. These results match with results of Agrawal et al., (2013) and Raju, (2013) who found an obvious increase in cellulase activity and fibrinolytic protease activity after EMS treatment of the Bacillus subtilis and Bacillus cereus respectively.

\section{Conclusions}

The isolate B16, which was isolated from Iraqi soil and characterized as Bacillus sp., is an efficient bacteria in producing thermophilic cellulase. From the values of enzyme activity assays carried on the control (wild) and mutated B16 isolate, it could be concluded that EMS is an active chemical mutagen since it was capable of enhancing thermophilic cellulase production in the mutant sample compared with control. The change in SD region might have enhanced the cellulase gene expression.

\section{Future Scope}

Iraq has a hot desert climate in $70 \%$ of its lands. Therefore, its soil contains a variety of thermophilic microorganisms which wait to be discovered and exploited in many industrial fields including enzymatic cellulose degradation, the growing renewal power field. New thermophilic species and strains of microorganisms economically desirable in the non-fossil fuel possessing countries, could be discovered, genetically modified and being exported to such countries which will represent a new financial source to the Iraqi financial revenues, especially to poor countries which cannot afford the expenses of importing fossil fuel.

Table 1: The biochemical tests results of the bacterial isolates (B16, B37, B39, B44)

\begin{tabular}{|c|c|c|c|c|}
\hline The biochemical test & B16 & B37 & B39 & B44 \\
\hline Gram stain & Gm+ve & Gm+ve & $\mathrm{Gm}+\mathrm{ve}$ & Gm+ve \\
\hline Catalase & positive + & positive + & positive + & positive + \\
\hline Starch & positive + & positive + & positive + & positive + \\
\hline Gelatin & positive + & positive + & positive + & positive + \\
\hline Motility & positive + & positive + & positive + & doubted \\
\hline \multicolumn{5}{|l|}{$\mathrm{pH}$} \\
\hline 5.7 & positive + & positive + & positive + & positive + \\
\hline 6.8 & positive + & positive + & positive + & positive + \\
\hline \multicolumn{5}{|l|}{ Salinity } \\
\hline $5 \%$ & positive + & positive + & positive + & positive + \\
\hline $7 \%$ & positive + & positive + & positive + & positive + \\
\hline VP mixed sugar hydrolysis & positive + & positive + & positive + & positive + \\
\hline MR complete g hydrolysis & positive + & positive + & positive + & positive + \\
\hline Lecithinase & positive + & positive + & positive + & positive + \\
\hline Anaerobic growth & positive + & positive + & positive + & positive + \\
\hline Indole & negative - & negative - & negative - & negative - \\
\hline \multicolumn{5}{|l|}{ Temperature $\left(\mathrm{C}^{\mathrm{o}}\right)$} \\
\hline 30 & positive + & positive + & positive + & positive + \\
\hline 40 & positive + & positive + & positive + & positive + \\
\hline 50 & positive + & positive + & positive + & positive + \\
\hline 55 & positive + & positive + & positive + & positive + \\
\hline 65 & negative - & positive + & positive + & negative - \\
\hline Spore stain & terminal & terminal & terminal & terminal \\
\hline Urea & positive + & negative - & positive + & positive + \\
\hline $\mathrm{H} 2 \mathrm{~S}$ & negative - & negative - & negative - & negative - \\
\hline \multicolumn{5}{|l|}{ Carbohydrate fermentation } \\
\hline Arabinose & positive + & positive + & positive + & positive + \\
\hline Glucose & positive + & positive + & positive + & positive + \\
\hline Mannitol & positive + & positive + & positive + & positive + \\
\hline Xylose & positive + & positive + & positive + & positive + \\
\hline Simmon's citrate & positive + & positive + & positive + & positive + \\
\hline
\end{tabular}




\section{International Journal of Science and Research (IJSR) \\ ISSN (Online): 2319-7064}

Index Copernicus Value (2016): 79.57 | Impact Factor (2015): 6.391

Table 2: VITEK 2 results for sample (16) identified according to this test as Bacillus licheniformis by the ratio $89 \%$

\begin{tabular}{|c|c|c|c|c|c|}
\hline No. of test & Test & Result & No. of test & Test & Result \\
\hline 1 & BXYL & - & 24 & dMAN & + \\
\hline 2 & LysA & - & 25 & dMNE & + \\
\hline 3 & AspA & - & 26 & dMLZ & - \\
\hline 4 & LeuA & - & 27 & NAG & + \\
\hline 5 & PheA & + & 28 & PLE & + \\
\hline 6 & ProA & - & 29 & IRHA & - \\
\hline 7 & BGAL & + & 30 & BGLU & + \\
\hline 8 & PyrA & + & 31 & BMAN & - \\
\hline 9 & AGAL & - & 32 & PHC & - \\
\hline 10 & AlaA & - & 33 & PVATE & + \\
\hline 11 & TyrA & + & 34 & AGLU & - \\
\hline 12 & BNAG & - & 35 & dTAG & + \\
\hline 13 & APPA & - & 36 & dTRE & + \\
\hline 14 & CDEX & + & 37 & INU & - \\
\hline 15 & dGAL & - & 38 & dGLU & + \\
\hline 16 & GLYG & - & 39 & dRIB & - \\
\hline 17 & INO & + & 40 & PSCNa & - \\
\hline 18 & $\mathrm{MdG}$ & + & 41 & $\mathrm{NaCl} 6.5 \%$ & + \\
\hline 19 & ELLM & + & 42 & KAN & - \\
\hline 20 & $\mathrm{MdX}$ & - & 43 & OLD & + \\
\hline 21 & AMAN & - & 44 & ESC & + \\
\hline 22 & MTE & + & 45 & TTZ & - \\
\hline 23 & GlyA & + & 46 & POLB_R & + \\
\hline
\end{tabular}

Table 3: VITEK 2 results for sample (37) identified according to this test as Bacillus cereus/thuringiensis/mycoides by the ratio $86 \%$

\begin{tabular}{|c|c|c|c|c|c|}
\hline No. of test & Test & Result & No. of test & Test & Result \\
\hline 1 & BXYL & - & 24 & dMAN & - \\
\hline 2 & LysA & - & 25 & dMNE & - \\
\hline 3 & AspA & - & 26 & dMLZ & - \\
\hline 4 & LeuA & - & 27 & NAG & + \\
\hline 5 & PheA & + & 28 & PLE & - \\
\hline 6 & ProA & - & 29 & IRHA & - \\
\hline 7 & BGAL & - & 30 & BGLU & - \\
\hline 8 & PyrA & + & 31 & BMAN & - \\
\hline 9 & AGAL & - & 32 & PHC & - \\
\hline 10 & AlaA & - & 33 & PVATE & + \\
\hline 11 & TyrA & - & 34 & AGLU & - \\
\hline 12 & BNAG & + & 35 & dTAG & - \\
\hline 13 & APPA & - & 36 & dTRE & + \\
\hline 14 & CDEX & - & 37 & INU & - \\
\hline 15 & dGAL & - & 38 & dGLU & + \\
\hline 16 & GLYG & - & 39 & dRIB & + \\
\hline 17 & INO & - & 40 & PSCNa & - \\
\hline 18 & MdG & - & 41 & NaCl 6.5\% & + \\
\hline 19 & ELLM & - & 42 & KAN & - \\
\hline 20 & MdX & - & 43 & OLD & - \\
\hline 21 & AMAN & + & 44 & ESC & + \\
\hline 22 & MTE & + & 45 & TTZ & - \\
\hline 23 & GlyA & - & 46 & POLB_R & + \\
\hline
\end{tabular}

Volume 6 Issue 12, December 2017 www.ijsr.net

Licensed Under Creative Commons Attribution CC BY 


\section{International Journal of Science and Research (IJSR) ISSN (Online): 2319-7064}

Index Copernicus Value (2016): 79.57 | Impact Factor (2015): 6.391

Table 4: VITEK 2 results for sample (39) identified according to this test as Bacillus licheniformis by the ratio $93 \%$

\begin{tabular}{|c|c|c|c|c|c|}
\hline No. of test & Test & Result & No. of test & Test & Result \\
\hline 1 & BXYL & - & 24 & dMAN & + \\
\hline 2 & LysA & - & 25 & dMNE & + \\
\hline 3 & AspA & - & 26 & dMLZ & - \\
\hline 4 & LeuA & + & 27 & NAG & $(+)$ \\
\hline 5 & PheA & + & 28 & PLE & + \\
\hline 6 & ProA & - & 29 & IRHA & - \\
\hline 7 & BGAL & + & 30 & BGLU & + \\
\hline 8 & PyrA & + & 31 & BMAN & - \\
\hline 9 & AGAL & - & 32 & PHC & - \\
\hline 10 & AlaA & - & 33 & PVATE & + \\
\hline 11 & TyrA & + & 34 & AGLU & - \\
\hline 12 & BNAG & - & 35 & dTAG & + \\
\hline 13 & APPA & + & 36 & dTRE & + \\
\hline 14 & CDEX & + & 37 & INU & - \\
\hline 15 & dGAL & - & 38 & dGLU & $(-)$ \\
\hline 16 & GLYG & + & 39 & $\mathrm{dRIB}$ & - \\
\hline 17 & INO & + & 40 & PSCNa & - \\
\hline 18 & MdG & + & 41 & $\mathrm{NaCl} 6.5 \%$ & + \\
\hline 19 & ELLM & + & 42 & KAN & - \\
\hline 20 & $\mathrm{MdX}$ & - & 43 & OLD & + \\
\hline 21 & AMAN & - & 44 & ESC & + \\
\hline 22 & MTE & + & 45 & TTZ & + \\
\hline 23 & GlyA & + & 46 & POLB_R & + \\
\hline
\end{tabular}

Table 5: VITEK 2 results for sample (44) identified according to this test as Lysinibacillussphaericus / Lysinibacillusfusiformis by the ratio $98 \%$

\begin{tabular}{|c|c|c|c|c|c|}
\hline No. of test & Test & Result & No. of test & Test & Result \\
\hline 1 & BXYL & - & 24 & dMAN & - \\
\hline 2 & LysA & - & 25 & dMNE & - \\
\hline 3 & AspA & + & 26 & dMLZ & - \\
\hline 4 & LeuA & + & 27 & NAG & - \\
\hline 5 & PheA & + & 28 & PLE & - \\
\hline 6 & ProA & - & 29 & IRHA & - \\
\hline 7 & BGAL & - & 30 & BGLU & - \\
\hline 8 & PyrA & + & 31 & BMAN & - \\
\hline 9 & AGAL & - & 32 & PHC & - \\
\hline 10 & AlaA & + & 33 & PVATE & + \\
\hline 11 & TyrA & $(+)$ & 34 & AGLU & - \\
\hline 12 & BNAG & + & 35 & dTAG & - \\
\hline 13 & APPA & + & 36 & dTRE & - \\
\hline 14 & CDEX & - & 37 & INU & - \\
\hline 15 & dGAL & - & 38 & dGLU & - \\
\hline 16 & GLYG & - & 39 & dRIB & - \\
\hline 17 & INO & - & 40 & PSCNa & - \\
\hline 18 & $\mathrm{MdG}$ & - & 41 & $\mathrm{NaCl} 6.5 \%$ & - \\
\hline 19 & ELLM & + & 42 & KAN & - \\
\hline 20 & $\mathrm{MdX}$ & - & 43 & OLD & - \\
\hline 21 & AMAN & - & 44 & ESC & - \\
\hline 22 & MTE & - & 45 & TTZ & - \\
\hline 23 & GlyA & - & 46 & POLB_R & - \\
\hline
\end{tabular}

Table 6: Primers used in this study

\begin{tabular}{|c|c|c|c|}
\hline Primer type & Primer sequence & $\begin{array}{c}\text { Conc. } \\
\text { Pmol/ } \mu \mathrm{l}\end{array}$ & $\begin{array}{l}\text { Product } \\
\text { size }\end{array}$ \\
\hline F-PR & 5'-GTTCGTGCTACAGGCAAGGA-3' & 100.9 & \multirow{2}{*}{$170 \mathrm{bp}$} \\
\hline R-PR & 5'-TTCGGTGCAATGATACCGCT-3' & 107.1 & \\
\hline F-TR & 5'-GGAAAGCTGATTTGGGGCAC-3' & 123.1 & \multirow{2}{*}{$240 \mathrm{bp}$} \\
\hline R-TR & 5'-CCGGTCCATTGATCGTGTCATA-3' & 114.5 & \\
\hline F-16S rRNA & 5'-AGAGTTTGATCCTGGCTCAG-3' & 104.1 & \multirow{2}{*}{$1512 \mathrm{bp}$} \\
\hline R-16S rRNA & 5'-TACGGCTACCTTGTTACGACTT-3' & 149.4 & \\
\hline F- Gyrase B & $5^{\prime}-$ AK$^{*}$ ACGGAAGTCACGGGAAC-3' & 100.8 & \multirow{2}{*}{$550 \mathrm{bp}$} \\
\hline R-Gayrase B & 5'-AGAAACTTTTCR ${ }^{* *}$ AGCGCTT-3' & 109.8 & \\
\hline
\end{tabular}

(PR): Refers to cellulase gene promoter region

(TR): Refers to cellulase gene terminator region
* $\mathrm{K}$ means $\mathrm{G}$ or $\mathrm{T}$ according IUPAC codes

** $\mathrm{R}$ means $\mathrm{A}$ or $\mathrm{G}$ according IUPAC codes

\section{Volume 6 Issue 12, December 2017} www.ijsr.net

Licensed Under Creative Commons Attribution CC BY 
International Journal of Science and Research (IJSR)

ISSN (Online): 2319-7064

Index Copernicus Value (2016): 79.57 | Impact Factor (2015): 6.391

Table 7: The cellulase activity pre- and post EMS treatment at (50) $\mu \mathrm{g} / \mathrm{ml}$

\begin{tabular}{|c|c|c|}
\hline The assay type & Pre-treatment & Post-treatment \\
\hline Qualitative assay & $17.4 \mathrm{~mm}$ & $18 \mathrm{~mm}$ \\
\hline Semi-quantitative assay & $24.3 \mathrm{~mm}$ & $17.5 \mathrm{~mm}$ \\
\hline Quantitative assay & $0.59 \mathrm{U} / \mathrm{ml}$ & $1.21 \mathrm{U} / \mathrm{ml}$ \\
\hline FPase assay & $1.39 \mathrm{U} / \mathrm{ml}$ & $1.85 \mathrm{U} / \mathrm{ml}$ \\
\hline
\end{tabular}

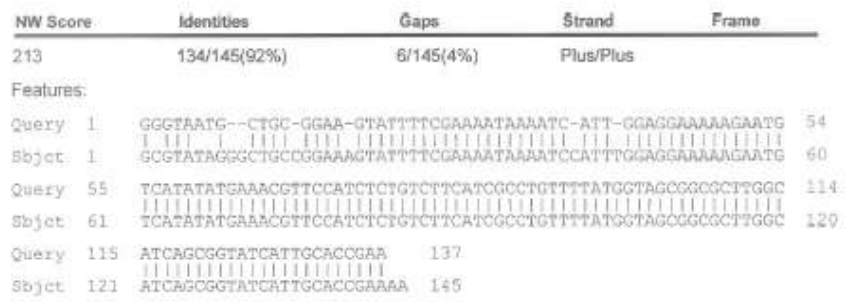

Figure 1: Alignment results of B16 isolate promoter region post-EMS treatment

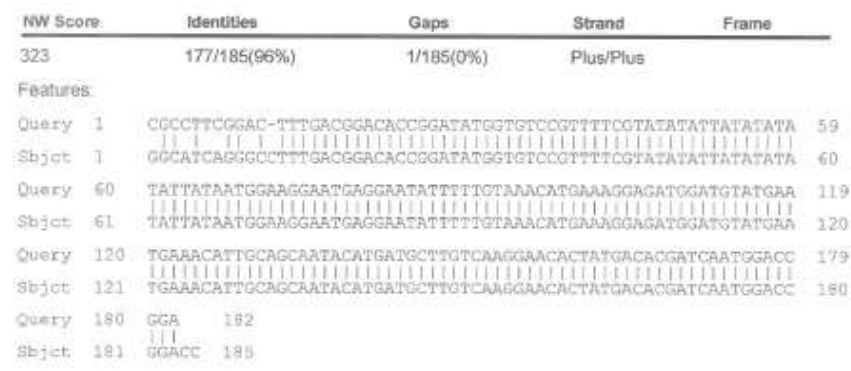

Figure 2: Alignment results of B16 isolate terminator region post-EMS treatment

Table 8: Changes in the sequence of transcription regulatory elements of cellulase gene post-EMS

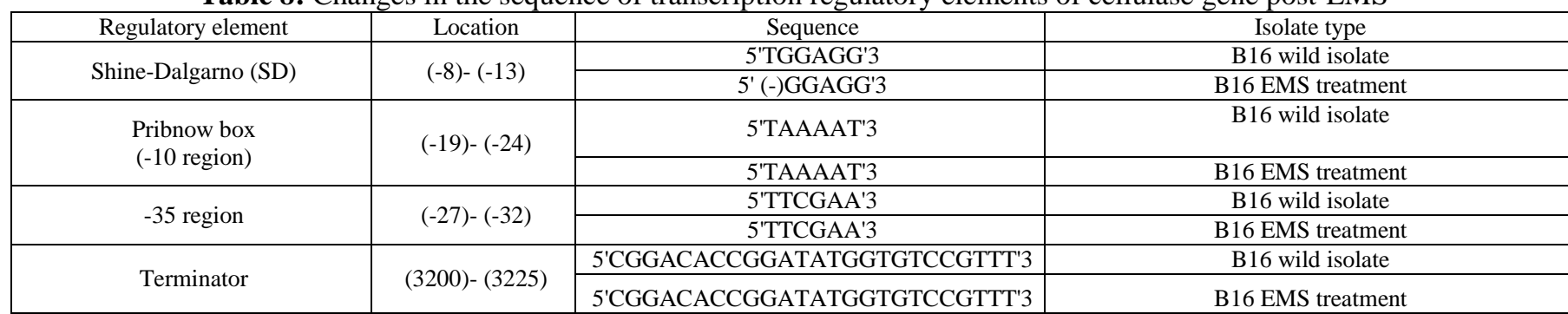

(-): refers to nucleotide deletions

\section{References}

[1] Abdullah, R.; Zafar, W.; Nadeem, M.; Iqtedar, M.; Kaleem, A. and Naz, S. (2016).Partial purification and characterization of cellulases produced by Bacillus strain. Romania biotechnological letters.Vol.21 (1): 11103 .

[2] Acharya, A.; Joshi, D.; Shrestha, K. and D.R. Bhatta, D. (2012).Isolation and screening of thermophilic cellulolytic bacteria from compost piles.Journal ofscientific world.Vol.10 (10):43-44.

[3] Agrawal, R.; Satlewal, A. and Verma, A. (2013).Development of a b-glucosidase hyperproducing mutant by combined chemical and UV mutagenesis. Biotechnology journal. (3):381-388.

[4] Ali, N.; Athar, M.; Khan, Y.; Idrees, M. and Ahmad, D. (2014).Regulation and improvement of cellulase production: Recent advances. Journal of natural resources, issue 5: 857-863.

[5] Haq, S.; Saleem, A.and Javed, M. (2009) Mutagenesis of Bacillus licheniformis through ethyl methanesulfonate for $\alpha$ - amylase production. Pakistan journal of Biotechnology. Vol 41: 1489-1498.
[6] Ho, H. and Chor, X. (2015).Improvement of xylanase production by Bacillus subtilis in submerged fermentation after UV and chemicals mutagenesis. Journal of advances in biology and biotechnology.Vol.3 (2):57-42 .

[7] Huang, C.; Chang, M.; Huang, L. and Chu, W. (2012).Development of a novel PCR assay based on the gyraseB gene for species identification of Bacillus licheniformis. Mol cell Probes. Vol. 26 (5):215-217.

[8] Ibrahim, A. and El-diwany, A. (2007).Isolation and identification of new cellulases producing thermophilic bacteria from an Egyptian hot spring and some properties of the crude enzyme. Australian journal of basic and applied sciences.Vol.1 (4):473478.

[9] Juturu, V. and Wu, J. (2014).Microbial cellulases: Engineering, production and applications. Journal of renewable and sustainable energy reviews.Vol.33:180-190.

[10] Karanam, S. and Medicherla, N. (2008). Enhanced lipase production by mutation induced Aspergillusjaponicus. African journal of Biotechnology. Vol. 7: 2064-2067. 


\section{International Journal of Science and Research (IJSR) \\ ISSN (Online): 2319-7064 \\ Index Copernicus Value (2016): 79.57 | Impact Factor (2015): 6.391}

[11] Kauri, T. and Kushner, D. (1985).Role of contact in bacterial degradation of cellulose.FEMS Microbiology Ecology journal.Vol.31:306-301.

[12] Kim, Y.; Schumaker, K. and Zhu, J. (2006).EMS Mutagenesis of Arabidopsis.Page 101 in J. Salinas and J. J. Sanchez-Serrano editors.Methods in molecular biology.Human press incorporation, NewJersy, USA.

[13] Klemm, D.;Schmauder, H. and Hienze, T. (2002).In Biopolymers.Wiely-VCH, Wienhiem.Vol. 6:290-292.

[14]Malys, N. (2012)."Shine-Dalgarno sequence of bacteriophage T4: GAGG prevails in early genes. Molecular biology reports. 39 (1):339.PMID21533668

(https://www.ncbi.nlm.nih.gov/pubmed/21533668).do i:10.1007/s11033-011-0707-4 (https://doi.org/10.1007\%2Fs11033-011-0707-4).

[15] Menendez, E. ; Garcia-Fraile, P. and Rivas, R. (2015).Biotechnological applications of bacterial cellulases:A review.Vol. 2 (3):163-182. microbiology. McGraw-Hill. USA.

[16] Minde, D.; Anvarian, Z.; RudigerS.and Maurice, M. (2011). Messing up disorder: how do missense mutations in the tumor suppressor protein APC lead to cancer?.Journal of Molecular Cancer. Vol.10 (101):29.

[17] Ponnambalam, A.; Deepthi, R. and Ghosh, A. (2011).Qualitative display and measurement of enzyme activity of isolated cellulolytic bacteria.Biotechnology, Bioinformatics and Bioengineering journal.Vol.1 (1):33-37.

[18]Raju, E. and Divakar, G. (2013).Bacillus cereus GD 55 strain improvement by physical and chemical mutagenesis for enhanced production of fibrinolytic protease.International journal of pharma sciences and research.Vol. 4 (5):81-93.

[19] Rhaese, H. and Boetker, N. (1973). The molecular basis of mutagenesis by methyl and ethyl methanesulfonates.European journal of biochemistry. (23):166-172.

[20] Samira, M.; Mohammad, R. and Gholamreza, G. (2011). Carboxymethylcellulase and filter-paperase activity of new strains isolated from Persian Gulf. Microbiology Journal.Vol. 1 (1): 8-16.

[21] Waldeck, J.;Daum, G.;Bisping, B. and Meinhardt, F. (2006).Isolation and molecular characterization of chitinase-deficient Bacillus licheniformis strains capable of deproteinization of shrimp shell waste to obtain highly viscous chitin. Applied and environmental microbiology.Vol.72 (12):7879-7885.

[22] Yeoh, H.;Khow., E and Limm, G. (1985).A simple method for screening. Cellulytic fungi Mycologia.Vol.77:161-162
Author Profile

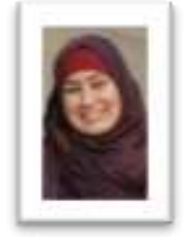

Ebtesam Basheer

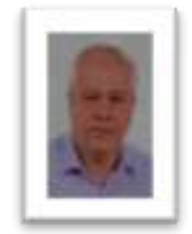

Ehab D. Salman 